\title{
Portage and Labour in Northern Middle Congo from 1900 to 1960
}

\author{
Dr. Dominique OBA
}

Ecole Normale Supérieure, Université Marien NGOUABI, Brazzaville, CONGO, 263

\begin{abstract}
This study shows that between 1900 and 1960, a partial view of the port and the workforce in the north of Middle Congo. Indigenous were enlisted against their will in a production system they did not know its contours. Porting when discussing these different contours in a negative way contributes to increasing misery and poverty, as many people were forced to leave their villages in order to escape brutal and repressive methods used for the whites recruit labor. It is therefore a system that had amplified the horror and even the spread of disease and starvation. The French Congo so enormous sacrifices needed for its development
\end{abstract}

Keywords: Portage, labour, northen middle Congo

\section{Introduction}

The Middle Congo is part of what can be called the French Congo composed of Gabon, Middle Congo, Ubangi Shari and Chad since the decree of 30 April 1891. With the decree of the French Congo 15 January 1910 became French Equatorial Africa, in opposition to the Belgian Congo and Portuguese possessions in Angola and Cabinda. All four territories of French Equatorial Africa covers an area of 2.75 million $\mathrm{km} 2$ for over an estimated population of over 4 million inhabitants before 1900 .

Northern Middle Congo which is devoted this study conventionally begins north of Brazzaville. This is a North that ignores the geographical equator, which includes the regions of trays, of the bowl, Sangha and Likouala, mainly dominated by grassland and countless courses water in the northernmost part. This study attempts to show how the porting and labor were a strength and a working medium during the first half of the twentieth century. Workers under contract have had mixed fortunes in terms of their remuneration. The consequences were as dramatic reading multiple stories and written materials often remained secret.

\section{1 -Historical facts}

The development of North-Congo really begins with the concessionary companies which from March 28, 1899, obtain concessions to French Congo. The development of a territory involves not only capital but also in equipment and manpower, Away from the metropolis, the colonial administration used the indigenous. About that:

The limited resources of the companies demanded that production and delivery should be ensured by Africans. But they refused to intervene voluntarily in the new circuit. Limited needs, prohibitively expensive techniques that they knew nothing did not encourage them to answer the call of whites often brutal or clumsy they had learned on major roads to flee the requirements. The passage of considerable material Mission Marchand upward Nile (1896-1898) in particular had to impose the implementation of a port unpopular tragically marked by rebellions and repressions especially in Loango (1)
It is in these conditions that the porting took precedence over all colonial activities especially between 1880 and 1950 in the North of the Middle Congo. The establishment of the slopes, the erection of bridges, construction of buildings require labor-intensive and often underpaid.

\section{2- Porting}

It concerns all actors of colonization beginning with administrators. The penetration of the North Middle Congo necessitated genuine fieldworkers from 1900. Next colonial literature this is the period of pacification within the areas hitherto remained vacant. So the administration based on targets set earlier organized in often difficult conditions porting to very dangerous slopes North -Congo. Thus, in the so-called pacification trays, Patrice Onka that studied the issue said:

Party on 21 May, under the leadership of Lieutenant Briaud, detachment from Brazzaville was to join that of the Pangala May 22. These two detachments met ... gave a staff of 79 guards. The new detachment, thus formed then left Pangala the June 4, accompanied by 79 porters to transport ammunition, spare food and various (2)

These carriers traveling to Ndolo locality Djambala capital of the region of Alima-Léfini (riding Batéké). In his study of Likouala Mossaka Georges Mazenot also mentioned carriers who serve various agents; directors, dealers and missionaries since 1885 until early 1900

1) Coquery Vidrovitch (C) 1969 Congo during the great concessionary companies 1898-1930, Paris, Mouton and Co., The Hague, p. 267

2) Onka (P) $1983 P$ e $n$ e tration and Occupation of countries Bat $k$ é é (Congo - Brazzaville) 1911-1917, MA-University of Marseille-Provence Brief p.

Also this exploration phase she raised a large number of Congolese porters. Apart from equipment to transport, administration of mail carriers used where the expression of courrier- pedestrian in areas of savannah and dry forests as the Central Plateaus (Djambala- Lékana- Gamboma)

In the Congolese Basin, as in the Sangha, the administration also pedestrian-mail used the boatman. In the far northeast 


\section{International Journal of Science and Research (IJSR) \\ ISSN (Online): 2319-7064 \\ Index Copernicus Value (2013): 6.14 | Impact Factor (2014): 5.611}

region of Likouala- Mossaka, colon enlisted in the mudflat of tipoye carriers between Impfondo and Epena totaling $80 \mathrm{~km}$ in other words two days canoe at high water and low water 4to 5 days with transshipments. It is often in the presence of true convoys organized by the administration and escorted by armed militiamen.

Religious missionaries are the second wave of those employed did the carriers also used the same channels that administrators deep savannas, forests and swamps of northern Middle Congo. The missions that have emerged here was with the help of indigenous carriers and memories of these are still alive in this regard. These two highly visible waves consist of administrators, explorers and missionaries have joined local leaders who used their subjects by order of administration. On the slopes, away from the posts, the militia force employed unexpected carriers unwary lingering in villages often abandoned.

Finally, dealers formed the third group of foreigners who used the back or the native head in northeastern Congo 1900à1960. Sixty years of hard work, the concessionary companies who organized this traffic were: the company's Léfini the Nkeme-Nkeni, Alima, the Alimaïenne, the French company's top Congo who later became French Company of up and down Congo (CFHBC) very famous Tréchot brothers Society of Equatorial Sangha and company Ngoko Sangha.

Of these only the CFHBC companies experienced a real boom at the same point to substitute in some parts to the local administration. So:

It appears that the lack of resources made available to the administrator Loukolela considerably limited the scope of its activities and in particular prevents react at the time of the first serious incidents that broke out during the second quarter of année1901 in the concession of CFHBC. This means if the administrative presence was erased during the difficult period of the beginnings...

In fact, dealers are accommodated fairly well this deletion that left them free to do as they please, or nearly so (3)

In the factories and on construction sites, dealers were often intractable and holders used the same methods: transportation on their backs or on their heads, traveling by canoe, use of tipoyes tireless running. The Congolese carrier remained in the center of the colonial economy one machine to do everything which constitutes both a strength and a working medium.

\section{3- Porting Nature}

In this no man's land porting first concerned the men that is to say the explorers and administrators and their luggage that had to be transported on men's backs and tipoye on very painful stretches through the course water. That's what said Nsondé (D) on the Brazzaville-Mindouli stretch:

The tipoye is carried by a team of people who take turns $8 a ̀ 16$... we had 16 porters for Lendi commander in close rotations. (4)
This could not be otherwise in the northern part of the Middle Congo. Deals with the products (hardware, weapons, liquor and fabrics) and equipment occupied the second place.

matches, soaps and articles of iron ... In large quantities there was salt, salt, rice and alcohol (5). At these products were added later, the goods dealer companies, they had set up along the river and through the savannas of northern Middle Congo multiple factories and workshops;according to a recent study:

3) Mazenot (G) 1976 The Likouala Mossaka, History of e $n$ e p tion of Upper Congo 1878- 1920, Paris, The HagueMouton volume1 p. 351

4) Nsondé (D), 1986 The CFCO and the Congolese living in Brazzaville Mindouli, DESd'histoire- Memory University Marien Ngouabi p.137

5) Makembou (G) 2001 The porting Lwango Nkuna to between 1880 and 1934, ENS CAPES thesis University Marien Ngouabi p. 35

Among these goods, the inventory can be made of tin hardware, machetes and knives, needles and son, enameled pots and pans. In addition, there are cans partially empty since they then used containers. To this list are added the small mirrors, beads and bells first necessity items like candle,

Finally, in third place came the trafficking and plantation products such as rubber, ivory, kola nuts, copal, sisal, coffee, oil palm and cassava for feeding yards.

\section{4- Frequency and Compensation}

There was no legislation. The port was left to the discretion of the White Master and auxiliaries. If in southern Congo, porting was momentarily slowed with the opening of the railway Matadi-Kinshasa in 1898, French Congo in 1900, the Education Committee and the interests of dealer's defenses, meeting in Brazzaville on 10mai listened Henri Tréchot demand the reopening of the portage trail.

On 13 May 1900 his appeal was heard. In northern Congo porting was organized throughout the year both in wet weather during the dry period. The Congolese remained in the transportation center near the river axis. He could not have respite with nightfall. The holidays do not exist except the commander or the dealer. To go from one point to another remote $50 \mathrm{~km}$ holders put such a day and a half walk. The charge for each individual 30et was around $50 \mathrm{~kg}$. We noted many desertions and porting current revolts despite increased surveillance of guards.

If in 1934 the South Congo and crossed the railroad freed porting, inside North Middle Congo, it reached the same time its peak despite the intervention of CFHBC at certain points refueled by its boats. The remuneration of these often unfortunate carriers was the more precarious and less assured: a handful of salt, old rags that's the least that can be said to hear the survivors of this episode how painful. To this arsenal were added according to the whims of the colonizer few nest eggs while in the South Congo porting seemed well regulated: 


\section{International Journal of Science and Research (IJSR) \\ ISSN (Online): 2319-7064}

Index Copernicus Value (2013): 6.14 | Impact Factor (2014): 5.611

Those who leave and stop at Loango Loudima receive three bottles of rum, the first commitment is given, the second and the third from the back of which 14 cortades 4constituent ration immediately granted and 10 other savings paid late contract (6)

The booklet carrier did not exist in the North Congo for accounting However the commander, the missionary and the dealer kept accounting books and records, a kind of notebook carefully kept and to which access was often difficult. By this behavior the colonizer lost in the bush beyond the control of the central administrator; this was only by way of prevention as the Inspector Administrator, installed mostly in large centers did not bother to organize tours in the bush.

\section{5- Workforce in the North}

In the 1900s, during which the public funds were sorely lacking, we had to organize the Congo in the light of an absolute principle: the colony must be sufficient in itself. This imperative miss in 1905 to cost his job Emile Gentil. Northern Middle Congo did not escape this basic principle regarding labor in different sectors. In the implementation of the slopes, the administration creates a menders body responsible for the maintenance of road sections, construction of bridges to allow the movement of agents and business of state and transport goods. Indeed until 1905, there was no AEF $20 \mathrm{~km}$ of roads.

Campaign plans were programmed annually by the administration which required a large workforce composed mainly of male strength. In the Congo Basin where bridge construction required more human effort, costs were often seen on the rise; day of operation was $\$ 0.80$ to 1 franc and the daily cost of the work estimated at over 30 francs regarding all workers and very often they were content with a simple diet, the savings being postponed or end of the work.

The tracks were arranged and marshy slopes crossed by wooden pavements roads. Labor for maneuver was estimated at the average price of the day at 0.509 francs and daily labor costs on Teke Trays amounted to 26.87 francs (7).

6) Mouyabi (D), 1986 The trail of slaves and portages, Master thesis, University Marien Ngouabi p.55

7) Abandzounou (PE), The colonial policy of France in the riding of Alima- Léfini 1910-1918, Master Thesis, University Marien Ngouabi p.67

The second sector which absorbed a large workforce was that of building. Lack of trained masons, administration and missionaries appealed to the local workforce, consisting essentially of bricklayers and masons apprentice administrator or missionary remained chief engineer. It is in these precarious conditions that the first public buildings sprang up across the North Middle Congo between 1910 et1930.

The true professional masons' body was formed after 1940. Workers' wages were gradually improved and many masons were finally engaged in the public service since 1950 . With concessionary companies, the housing sector and construction experienced a notorious development. It was first build factories perishable materials then durable materials when resources permit. This sector is by far one of the most important of all settlement activity. It gradually transformed the space, small villages, the Northern Middle Congo saw the appearance of very large urban areas such as the capitals of regions and districts. The large colonial plantations also occupied a place in the activity of dealers. It was for the Congolese basin of the crop of oil palm with CFHBC which had the monopoly for that she benefited from the support of public administration.

She used at this level of thousands of individuals, but the results were almost poor:

Economically the CFHBC makes the law. Or did she pull that? Approximately 4,400 tons of products were shipped in 1950 Mossaka Brazzaville. Little in this tonnage, apart from palm oil or palm almonds. Divide it onto the operated area: $100 \mathrm{~kg}$ oil is obtained or almonds per square kilometer, $1 \mathrm{~kg}$ per hectare. The account per capita does not look better: thirty kilograms for each individual, about 150 for a family of five: either an individual income of 300 francs, a family income of 1500. The amount of work expended is in keeping (8).

It is here that the idea of exploitable mass and the degree of its operations by dealers. This operation is very sensitive phenomenon on Teke Trays regarding cash crops between 1945 and 1960. Indeed, the peasant communities were organized by the department of industrial exploitation of tobacco it employed mostly men who themselves leaned on a female workforce often poorly paid.

8) Sautter (G) 1966 From the Atlantic to the Congo River, a geography under - development, The Hague, Paris, 2volumes, p.789

The mode of colonial production that is rooted at this level anyway alienated the work of women in favor of men and foreign operators. In any event, in the north of the Middle Congo, the plantation economy was long the initiative of the natives themselves except in public works.

Often the native North did not know the difference between the administrator, missionary and the dealer. For him, the orders came from the new master Blanc. How many people were they employed by the White entre1900 and 1960s in northern Middle Congo? Impossible to know the current state of research.

In any event, in the north of the Middle Congo, the plantation economy was long the initiative of the natives themselves except in public works. Often the native North did not know the difference between the administrator, missionary and the dealer.

For him, the orders came from the new master Blanc. How many people were they employed by the White entre 1900 and 1960s in northern Middle Congo? Impossible to know the current state of research. Most indigenous workers- It will be recalled that only stood under various contracts and 


\section{International Journal of Science and Research (IJSR) \\ ISSN (Online): 2319-7064}

Index Copernicus Value (2013): 6.14 | Impact Factor (2014): 5.611

special status; seasonal jobbers, employee volunteers more or less short, Kapita, village chief, earth or township, junior officers drawn from all traditional backgrounds.

\section{Evolution and Consequences}

If between 1900 and 1934 when we witness the opening of Congo Ocean Railway, porting has probably reached its peak in the north of the Middle Congo, it should be noted that:

Porting a man's back is almost unknown today ... and when an officer is required to travel on a tour, one is obliged to use to transport his luggage and that of a team of prisoners, no free native only willing to commit to this service (9).

This behavior is explained by the opening of routes with heavy traffic and setting auto march from de1945 by cons, especially labor Free diminished significantly between 1950 and 1960 (1960 being the year of the independence of the Congo). 9-Coquery Vidrovitch (C) 1969 Congo during the great companies dealerships 1898-1930, Paris, Mouton \& Co., The Hague, p.435

The consequences were up to the tasks required to indigenous, they are demographic, first; Indigenous subject to port and various recruitments made vacuum around them where the abandonment of entire villages. Many carriers and in various contract workers were killed on the slopes and on construction sites, death due to disease and accidents. The coercive porting the first half of the twentieth century worked only on the basis of human energy.

Thus in 1900, the populations of North Congo incorporated by force into the colonial economy with the imposition of personal taxes could not really focus on the village economy. Famine settled in parts subjected to colonial abuses and exaggerations, before this is accomplished, the native Congolese could not react with energy.

\section{Acknowledgements}

We thank everyone who helps us in this scientific work

\section{Conclusion}

As seen 1900A of 1960, the French Congo remained about the center of the colonial generation constituting a must suddenly work force. The foundations of traditional society of Northern Middle Congo were deeply shaken by the colonial practices and subject peoples were not made at the discretion of the colonizer. The natives now oscillate between the old structures and the new way of life imposed from outside. Social and professional categories were born and this is by far the brand the North society of the Middle Congo and by extension of French Equatorial Africa. Rightly we can speak here of historical mutations that occur in the traditional Congolese society between 1900 and 1960.

\section{References}

[1] Abandzounou (PE), 1981, The colonial policy of France in the riding of Alima-Léfini from 1910 to 1918, Master Thesis, University Marien Ngouabi 102p.

[2] Coquery Vidrovitch (C), 1969, Congo during the great concessionary companies from 1898 to 1930, Paris, Mouton and Co., The Hague, 502p.

[3] Makembou (G), 2001, Porting Lwango to Nkuna between 1880 and 1934, CAPES-ENS thesis, University Marien Ngouabi 45p.

[4] Mazenot (G), 1976, The Likouala Mossaka, history of the penetration of Upper Congo 1878-1920, Paris, The Hague, Mouton, 1volume 455p.

[5] Mouyabi (D), 1986,The trail of slaves and portages, Master thesis University Marien Ngouabi, 69p.

[6] Nsondé (D), 1986, The CFCO and the Congolese living in Brazzaville to Mindouli, DES history thesis, University Marien Ngouabi, 263P.

[7] Onka (P), 1983, Penetration and occupation Batéké countries (Congo - Brazzaville) 1911- 1917 Master Thesis-University of Provence-Marseille I, 173P.

[8] Sautter (G), 1966, From the Atlantic to the Congo River, an underdevelopment of Geography, Paris, The Hague, 2 volumes, $1102 \mathrm{p}$. 